\title{
Quality inTeacher Education - Various Parameters andEffective QualityManagement
}

\author{
Dr. Rajib Mukhopadhyay \\ Faculty, Department of Education, St. Xavier's College 30, Park Street, Kolkata, PIN-712235, W.B., India
}

\begin{abstract}
Education in general and teacher education particularly, is deliberate enterpriseaimingto providegood quality service to its customers in order to enable them to contribute significantly for development of the nation.This quality service is essential in the modern context of globalization. Quality in teacher education is the area of focal interest of the present study. Conceptual framework of quality has been discussed in details. Various quality parameters in the field of teacher education have been identified and few major among them have been explained elaborately. The study has also discussed the important role of quality management in teacher education, which is a programto integrate all these quality components to ensure accountability, commitment and credibility of the institution enabling it to render a customer friendly service.

Key words: quality, teacher education, quality indicators, total quality management
\end{abstract}

\section{Introduction}

The purpose of teacher education is to produce teachers who have competencies in various fields. The role of teachers is no longer confined in teaching by imparting knowledge only, they need to be thorough professionals, fully equipped with high academic standard, pedagogical skills, ethical and moral values etc (Singh, 2008). In fact, they have to play a multi-tasking role in the context of various challenges emerging in the field of contemporary society. In this connection, the role of teacher education has also increased many folds. It has special roles to prepare future teachers who are socially responsible and conversant with unique features of cultural heritage and various socio-cultural ethos, have high commitment and the ability to lead society and nations shaping young minds of the learners.

Unfortunately the programs of teacher education are alleged to be static and stagnant. In spite of many innovations in this area abroad, situation in India is not up to the mark. Here teacher educators repeat and experiment their own training, which they received earlier upon their students. The existing teacher education model is inherited mostly from British system of education and is suffering a lot due to its inability to keep pace with time adopting necessary modification in its conceptual based theory and practices (Yadavetal., 2011). N.P.E. (1986) and the subsequent program of actions have realized that the program of teacher education in various stages requires a thorough reconstruction in its input, process and out put in order to make the system quality oriented. The international Commission on Education for $21^{\text {st }}$ century has also recognized necessity of reshaping this program in order to enhance its quality in various aspects. Though recently there is quantitative expansion, many things are yet to be done to ensure its quality (Kapoor, 2009). Question arises in this regard-

What is the conceptual meaning of the term quality?

What are various quality parameters deemed appropriate in this particular field?

How to implement all this parameters following an effective scheme of quality management?

Answers of these questions have been sought in the present study. These are discussed step by step as follows.

\section{Quality: A Conceptual Framework}

'Quality' is highly debatable theme. It is the goal of an eternal quest through the corridor of human history, the driving force for the entire human endeavor. According to oxford English dictionary (in Yadavetal., 2011) the notion of 'quality' includes all the essential attributes of an individual or object indicating its value and acceptability to the other. The British Standards Institution (1991, in Mukhopadhyay, 2007) defines 'quality' as the totality of features of characteristics of a product or service that bear upon its ability to satisfy the stated or the implied needs. In the modern context of globalization, the term quality emphasizes on meeting customer expectations. Customer can be external or internal. External customers are the recipients of an output, but are not part of the organization supplying it; whereas internal customers are the recipients of another person's or department's output within an organization (Bayer, 1997).

In the field of education- students, faculty members, administrative staff, management etc. are the internal customers; and the community, government etc.are the external customers. Stake holders include both internal and external customers, to whom quality is ultimately meaningful. Assurance of quality and standards of higher education is now widely recognized as a fundamental pre-requisite criterion. In view of the importance 
of quality there is an urgent need in the country towards the development of knowledge and understanding of the practice of quality assurance in higher education (Dahiya, 2001).

In fact quality in education is a matter of global quest. In order to succeed in this and to attend global standards in local settings, it is necessary for Indian educational institutions to improve and sustain the quality. Quality in the present era has proved to be a decisive factor in determining the success or failure of any service (Singh, 2008).

In fact, quality, now a days, has become a key word of any system due to emergence of the issues liberalization, privatization, and globalization; where everybody has got the scope to show his/her own wealth.

To ensure quality in education (as well as in teacher education particularly), is a massive challenge since it deals with the most sensitive creation of earth i.e. the human resources (Rogers, 1995). Industrial products are finished goods. Nothing can be done once they are finished. One can look for a better quality only in next time. Therefore, the concept of quality in industry has an objective basis and is less critical. But in education (including teacher education also), there is no such finished product. Human resources, whom it deals with, are always on the way 'to be'; they continue to learn and evolve (Rogers, 1995). Education in general, facilitates this continuous evolution of an individual. Therefore, the quality criterion in this context is multi-dimensional, more subjective, and critical, as well. Teacher education is responsible for producing quality teachers, where identification of quality norms and the process of their operationalization is extremely complex (Yadavetal., 2011).In the context of teacher education, quality refers to pursuit of excellence, consistency of fairness, satisfaction of client needs, and appropriate identification, utilization of various resources and also further generation of resources leading to achievement of institutional goals (Arya, P.P., 2006).

Quality has various aspects which need to be integrated coherently and also to be implemented in order to achieve the expected goal (Singh, 2008). Here lies the role of an effective program of quality management. Deming's have identified four major pillars of quality management viz. to Plan, to Do, to check and to Act again (PDCA model, in Yadavetal, 2011). Synergic relationship, continuous improvement, self-evaluation, leadership etc. are the essential components of it. Quality management is a process of value addition, conformance of education output to planned goal, specifications and requirements, as unique opportunity to respond to global challenges in achieving an expected outcome and to serve better for their stakeholders (Mukhopadhyay, 2002).

\section{Quality Parameters}

In the field of teacher education, the major quality indicators namely- curriculum design; curriculum transaction; evaluation system;research and development; infrastructure and learning resources; student support and progression; organization and management etc. have been identified by researchers. Special emphasis is also given on internship program, though it is considered under the broad category of curriculum. Few among these indicators are explained in details in the following sections.

\subsection{Curriculum design}

Curriculum in teacher education consists of two major components - theory and the practicum. Though teacher education is mostly a skill based program but conceptual understanding of those skill oriented activities might be a major concern of a teacher (teacher trainee). Therefore theory and practicum should have a justified proportion in the curriculum.Historical, Philosophical, Psychological, and Sociological aspects of education are four essential theoritical components. In addition, various contemporary issues and challenges emerging in the field of modern education should also be included there (Carr and Kemmis, 1986). The various concepts should be incorporated following the integrated approach in order to facilitate a comprehensive learning of the students. Various socio-cultural ethos and traditional features of Indian society, along with the discussion on different aspects of modern pedagogical developments might also be included. Particularly, the present status of teacher education in the context of liberalization, globalization, privatization, WTO-outsourcing will have to be considered essential also (Khanka, 2002).Simulated lesson, field survey, case studies, community outreach activities etc. should be included in practicum. Teacher education program in India should be designed also with due concern to Indian traditional value system, as well.The curriculum of teacher education at all stages has to emphasize this traditional identity. The influence of different racial, religious, social, linguistic and regional groups in developing India's composite culture and nationhood need to be clearly discussed in this program of teacher education (NCTE, 2004). There should also be the provision of curricular evaluation following a systematic and scientific approach. While revising, opinion from experts as well as different stakeholders should be utilized properly.New emerging social aspirations need also to be recognized. New experiences should be incorporated in the new curriculum in view of all these essential considerations (Arya, 2006).

\subsection{Curriculum Transaction}

Not only curricular development, major emphasis should also be given on effective transaction of curriculum in teacher education program. Presently, responsibility of the curriculum transaction is laid on the teacher educators who by and large use lecture method for this purpose. The prospective teachers (teacher 
trainees) are academically quite mature and can share the burden of their own study; therefore, the teacher educators should emphasize on self and independent study of the trainees, group learning and group discussion methods, peer group tutoring, learning through field trips and excursion, problem solving and preparation of projects (Singh, 2008). They should learn to prepare tests and evaluation tools. Learning by community participation and observation, workshops and seminar mode of teaching, teaching through radio counseling and teleconferencing technique etc. may also be practiced.

Preparation ofvarious self-learning packages using technology for the teacher trainees (preparation by the joint collaboration of teacher educators and technical experts) should alsobe encouraged. In case of teaching the laboratory practical, emphasis even now-a-days is being laid on mere experimentation only, what is usually practiced by school learners. But the underlying spirit of conducting experimentations in laboratory by a school student and a teacher trainee should not be identical. Instead of experimenting practical only, teacher trainees should also be acquainted with various ways of practicing the techniques of demonstrating thoseactivities to their peer members using various skills of simulated lessons.An exhaustive microteaching program may be followed using various cycles for improvement of the lessons practiced by the trainee teachers (where there will be the provision of repetitive video-recording of trainee teachers' performance) before starting the formal teaching practical program (Kapoor, 2009).

In addition, in view of multicultural nature of Indian society- teacher education program, in Indian context, should address diverse issues related to cultural lives of students in India. In this regard, the need of transacting curriculum through a multicultural mode is effective. Trainee teachers should be provided various cultural materials, and also the opportunity to understand and appreciate other cultures, and information about the characteristics and learning styles of various groups and individuals (Banks, 1997). In addition, students (trainee teachers) are taught various procedures by which they can gain information about the communities represented in their class rooms (Zeichner, 1996). They should also be taught how to assess the relationships between the methods they use in the classroom and the preferred learning and interaction styles in their students' homes and communities, how to use various instructional strategies sensitive to cultural and linguistic variations and how to adapt classroom instruction to accommodate the cultural resources that their students bring to school (Hixson, 1991). Judicious use of technology might provide teachers as well as their educators to facilitate learning through such a multicultural mode (Banks, 1997).

\subsection{Evaluation}

Evaluation of student teachers at this stage need to be comprehensive and continuous (Ahmand, 2008). Due importance should be given to the opinions of supervisors and school teachers who will maintain the record of the progress of student teachers. The capacity to organize thoughts and express them coherently, taking notes from reading materials and using teaching aids and ICT carefully at the appropriate moment need to be the major concerns of evaluation (Singh, 1990). Latest evaluation techniques as peer group evaluation of trainee teachers, self-assessment, evaluation in terms of teacher educators' opinion using rating scale etc. may be introduced. Formative as well as summative mode of evaluation both areessential. The semester-end examination should be accompanied by continuous evaluation also, on the basis of which feedback may be provided to the students. Continuous evaluation should be practiced throughout the entire course of the academic program. Evaluation should be made on the basis of grades and not on marks. Emphasis should be given on the internal examination, rather external one (Mukhopadhyay, 2007). That internal examination should also ensure its strong reliability minimizing the possibility of various mal-practices.Highly credible Semester based credit system should also be encouraged to ensure a better student friendly and credible evaluation system in teacher education.Criterion referenced system of evaluation may also be introduced in order to ensure a quality evaluation.

\subsection{Research in teacher education}

During the last five decades a large number of researches, surveys, etc. have been conducted in teacher education. Characteristics of effective teaching, curriculum evaluation, organizational climate and its impact on teachers' performance, the criterion for admission of prospective teachers and administration of education/teacher education have found to catch the attention of researchers. But planned and purposive approach has been found to be neglected. In a few universities only, teacher educators conducting/supervising researchers in various areas of education/teacher education are found (Ahmand, 2008). Majority of the researches conducted have been found to be ill-conceived, not connected with real problems of teacher education, and even done in extremely haphazard ways. Systematic approach and continuity are found to be lacking (Singh, 1990). Researchers working in this field often viewed teacher education in relation to some isolated concepts. Researches were found mostly skewed toward quantitative analysis only. Modern qualitative approach, which are becoming more popular in advanced countries, are not being used much in India (Singh, 2008). Researches do not have even much creditability among its intended clients, teacher educators and 
administrators working in this field. The courses of research methodology are weak. Researchers over emphasize certain areas and neglect others (Mukhopadhyay, 2007). Various subjects are taught as a compulsory component of teacher education curriculum, but with the exception of psychology and sociology of education, methods of study/research in most of the other fields do not attract the attention of teachers. Anthropology, history, philosophy, management, financing, planning and comparative education etc. are those extremely neglected areas (NCTE, 2004).

There is the need for recasting the whole program/curriculum of research methodology and use of statistics in it. Statistical jargons are used without understanding their meaning and relevance. Foreign tools are used mostly without due concern to its applicability in our context (Dahiya, 2001). Many of the researches in this particular field even are found to serve neither the utilitarian purpose nor do they cater the need of academic excellence. Research reports are not going through critical peer-group scrutiny. Review has become mostly a casual and non-serious exercise (Yadavetal, 2011). Researchers are found giving more emphasis only to the ultimate findings neglecting the conceptual framework of the study. Research papers usually are found to be prepared from $\mathrm{PhD}$ theses already submitted in universities and therefore these research papers are going to be mere replica of the original thesis. Once the thesis is submitted, authors are not taking proper care to update it before presenting or publishing further papers with reference to the same original thesis (Khanka, 2002).

Arbitrariness in research has been recognized as one among the major problems (Dave, 2007) in research in the field of teacher education. Arbitrariness means lack of meaningful relation among studies. Any research should be based on previous research for its assumptions, hypotheses and theoritical background. Only then,a hierarchical growth in the discipline is possible. Therefore it is important to establish proper linkage of teacher educators among themselves and also with various stakeholders working in this field in order to develop a coherent understanding of various related issues and concerns. This will help in identifying suitable research problems, avoids duplication in research and enhances the possibility that all aspects and variables involved are being attended to properly.

Thus it is important to have long term plans for research, a proper networking and collaboration among the teacher education institutions, availability of resources in terms of grants as well as effective guidance from expert research guide etc. may result in a quality outcome.

\subsection{Internship program}

Internship program is the core component of teacher education. There are wide variations in this program from institutions to institution. Not only that, there is a common practice to consider this program in the form of mere teaching practical- by delivering lectures only on the method subjects. Some problems have been identified by Mukhopadhyay(2007) which are as follows.

In most of the cases under the instruction of NCTE, trainee teachers practice thirty five to forty lessons on the same format without verifying the optimum number of lessons required by an average teacher trainee to achieve the peak of his teaching competence in that particular method. Lesson plans also only emphasize on Herbartian steps (Mukhopadhyay, 2007). General apathy of teacher trainee towards this program, as well as the same of the teacher educators to supervise the practice lesson are common problems. Following measures may be adopted in this case to ensure quality:

NCTE recommendation of 35-40 lessons needs to be verified with empirical evidence. Besides Herbartian styles of planning lessons, practice lessons in other forms of instruction like individualized instruction, group interaction, and problem solving through project or even media aided instructions may be practiced. Teacher educators should be adequately equipped to guide the trainee teachers in innovative instructional techniques (Kapoor, 2009). Exhaustive rating of practice teaching lessons (involving the essential skills) should be encouraged employing standardized tools and techniques. Besides teaching only the trainee teachers should also be acquaintedwith various other activities performed by teachers as maintaining records, organizing and assisting various co-curricular activities, student counseling, parent contacting, organizing examinations in order to acquire a holistic experience of a true internee.

\section{Quality Management In Teacher Education}

To maintain and enrich an overall quality of institution, all the separate quality components, as referred, need to be integrated by designing proper policy, systems, and processes. Here lies the role of an effective quality management.

Though the concept of quality management has been introduced mostly to improve the quality of industrial product, its relevance in the field of academic institutions has also been realized by educators. Particularly in the field of teacher education, its effective implementation might ensure a better possibility of increased involvement of various stake holders, more team work, the process of redesign, competitive benchmarking, constant measurement of the outcomes, long range vision, team based problem solving, and closer relationship with community (Kaun, 1996). 
Various essential necessary criterion and steps to be taken for an effective quality management program in teacher education has been suggested by Singh, G (2009, in Yadavet.al., 2011). These are as follows-

i. Commitment of management and governing body: Only profit making approach of management and governing body of a teacher education institute is a major cause of qualitative downfall of teacher education. Management should be accountable and committed to their service, have adequate concern ofvarious quality aspects and norms in the field of teacher education.

ii. Identification of Quality areas: Areas to which quality improvement is required arenecessary to identify.Teacher education institutions may consult various parameters identified by apex bodies like NAAC (namely curriculum design and planning, curriculum transaction and evaluation, research-developmentextension, infrastructure and learning resources, support system and progression, and, organization and management; NAAC : 2005) in this regard.

iii. Appointment of Quality Assurance Cells: Teacher education institutions should have its own internal quality assurance cell. It consists of a number of faculty members and the management personnel in order to monitor various functions of the institutionand suggest for the necessary improvements.

iv. Establishment of various steering committees: Identification of quality areas will lead to the subsequent identification of various tasks and to analyze those in view of their priority. Various committees may be formed in this regard and the tasks may be distributed among them.

v. Design of Process and Objectives: Objectives of each steering committee need to be formulated and operationalized in terms of achievable outcomes. Depending upon this, process of functioning of each committee may be decided.

vi. SWOT analysis: It is one of the most essential functions of various steering committees to identify strength-weakness-opportunity-threatin the related fields and to prepare the necessary plan of action in this regard.

vii. Awaring quality aspects: Assurance of quality is a team work. It is not possible without adequate awareness and involvement of all the concerned persons. Therefore all the stakeholders should be well informed about the quality criterion and various efforts planned and acted upon by the management to raise the quality standard of institution.

All the steps as discussed are the major concerns in the pre-active stage, ie before starting the actual operations. Next is the stage of implementing all the proposed plans and suggestions into actions; and also the steps necessary for monitoring and reviewing the entire process as post-operative considerations.

The implication of quality management in this way may help an institution to achieve quality in various fields by ensuring customer satisfaction, accountability, credibility, and thus to maintain a certain standard of excellence.

\section{Conclusion}

Confronted with declining standards, primarily due to expansion of higher education system, the question of quality become critical. Teacher education system is not the exception of it. In the name of development of education for access to maximum, self financing teacher education institutions are mushrooming now a days. The quantitative expansion has been accompanied by qualitative deterioration. In this context, quality management helps in designing the program to respond to global challenges to ensure a quality outcome in order to serve better for its customers.

\section{References}

[1]. Ahmand, S. (2008). UGC-NET :A Measure to Maintain Quality in Teaching And Research. University News, 46(21), May 19-25

[2]. Arya, P.P.(2006). Higher Education and Global Challenges-Systems and Opportunities, Deep and Deep Publications, N.Delhi

[3]. Banks, C. A. M. (1997) Multicultural education: Issues and perspectives, $3^{\text {rd }}$ ed. Boston: Allyn\& Bacon.

[4]. Boyer, E. (1997). Scolarshipreconsidered : priorities of the professoriate. (p.24). Princeton, NJ : The Carnegie Foundation.

[5]. Carr, W. and Kemmis, S. (1986). Becoming Critical: Education, Knowledge and Action Research. Basingstoke: Falmer Press.

[6]. Dahiya, L.N. (2001). Quality of Doctoral Research in India : Some Monitoing and Control Issues, University News, 39(45). Nov-511

[7]. Dave, P.N.(2007). The Decline of Quality Research in Education, Perspectives in Education, 23(1).

[8]. Hixson, J. (1991). Multicultural contexts for teacher education: Meeting the challenge of student diversity. Paper presented at the meeting of the American Educational Research Association, Chicago,IL

[9]. Kapoor, D.R.(2009). Dynamics of Learning Organizations. Regal Publications, N.Delhi.

[10]. Kaun P.Y.K. (1996) Application of Total Quality Management in Education: Retrospects and Prospects, International Journal of Educational Management, 10(5).

[11]. Khanka, S,S.(2002). Declining quality of doctoral research in indian universities. University news, vol-40, no.9, March-4-10

[12]. Mukhopadhyay, M. (2007). Education in India Dynamics of Development, Shipra Publication, N.Delhi

[13]. Mukhopadhyay, K.(2002). Total Quality Management in Education, NIEPA Publication.

[14]. NAAC (2005), Guidelines for Creating of the Internal Quality Assurance Cell (IQAC) in Accredited Institutions.

[15]. National Policy of Education (1986). MHRD Document, Govt of India, N.Delhi

[16]. NCTE. (2004). Some Specific Issues and Concerns of Teacher Education, NCTE, N.Delhi.

[17]. Programme of Action $(1990,1992)$. MHRD Document, Govt of India, N.Delhi 
[18]. Rogers, E. (1995). Diffusion of innovation $\left(4^{\text {th }}-e d\right)$. The Free Press: N.York

[19]. Singh, L.C. (1990). Teacher Education in India : A Resource Book, NCERT, N.Delhi

[20]. Singh, S.D. (2008). Quality Process Norms for Teacher Education System and Role of Teacher Educators. University News, 46 (96), 110-112.

[21]. Yadav, K., Khandai, H.K., Mathur, A. (2011). Innovation in Indian Education System., Shipra Publication, New Delhi.

[22]. Zeichner, K. M. (1996) Educating teachers for cultural diversity. In K. Zeichner, S. Melnick, and M. L. Gomez (Eds.), Currents of reform in preservice teacher education (pp. 133-175). NY: Teachers College Press 